\title{
Persepsi Masyarakat Terhadap Penerimaan Anggota Polri
}

\author{
Edi Saputra Hasibuan \\ Direktur Eksekutif Lemkapi dan Dosen Ilmu Hukum Universitas Bhayangkara Jakarta \\ Email: hedihasibuan@yahoo.co.id
}

Received : 6 Mar 2021 | Revised : 2 Apr 2021 | Accepted : 23 Apr 2021 | Published : 10 Jun 2021

\begin{abstract}
Talking about security and order in the State, it cannot be separated from the role of the Police. The creation of a conducive environment creates a sense of security and is tertiary. If this is achieved, the level of community welfare will increase in daily activities. The performance within the National Police has always been in the spotlight that shapes the perception of the community itself. The police as law enforcers and community protectors are important figures in society, even the dream of becoming a police officer is a hope for many people. Things related to the National Police always open opportunities for the best sons and daughters of the nation to participate and become part of law enforcers and state servants. In practice, the Police always prioritizes the motto "Clean, Transparent, Accountable, and Humanist" as evidence that admission of Polri members goes through a rigorous selection process. In this regard, the authors conducted research to see how the public's perception of the National Police, especially in the process of recruiting members.
\end{abstract}

Keywords: Recruiting, Polri, Perception

\begin{abstract}
ABSTRAK
Bicara mengenai keamanan dan ketertiban dalam Negara, tentunya tidak lepas dari peran Kepolisian. Terciptanya lingkungan yang kondusif menimbulkan rasa aman dan tertib, bila hal ini tercapai maka taraf kesejahteraan masyarakat akan meningkat dalam menjalani kegiatan sehari-hari. Kinerja dalam tubuh Polri selalu menjadi sorotan yang membentuk persepsi bagi masyakat itu sendiri. Polri sebagai penegak hukum dan pengayom masyarakat merupakan figur penting di tengah masyarakat, bahkan impian menjadi seorang anggota polisi menjadi harapan bagi banyak orang. Terkait hal tersebut Polri selalu membuka peluang bagi putra-putri terbaik bangsa untuk ikut dan menjadi bagian sebagai penegak hukum dan abdi Negara. Dalam prakteknya Polri selalu mengedepankan motto "Bersih, Transparan, Akuntabel, dan Humanis" sebagai suatu bukti bahwa dalam penerimaan anggota Polri dilalui dengan proses seleksi yang ketat. Berkenaan dengan itu maka penulis melakukan penelitian untuk melihat bagaimana persepsi masyarakat terhadap Polri khususnya dalam proses penerimaan anggota.
\end{abstract}

Kata Kunci: Penerimaan, Polri, Persepsi 


\section{PENDAHULUAN}

Masyarakat dan polisi adalah dua unsur yang berkaitan satu sama lain. Tanpa masyarakat tidak ada polisi, dan tanpa polisi proses-proses dalam masyarakat tidak akan berjalan lancar dan produktif. Kenyataan tersebut membuat Polri dalam menjalankan tugasnya mempunyai peran ganda, yaitu sebagai penegak hukum juga sebagai pekerja sosial (social worker) pada aspek sosial dan kemasyarakatan (pelayanan dan pengabdian). ${ }^{1}$

Kepolisian merupakan institusi pemerintah yang bertugas dan bertanggung jawab akan keteraturan sosial, Kamtibmas (keamanan, ketertiban dalam masyarakat) dengan tugas pokoknya melindungi, mengayomi, melayani masyarakat dan menegakkan hukum. ${ }^{2}$ Dalam melaksanakan perubahan dan reformasi ditubuh Polri upaya untuk menciptakan Polri yang promoter (profesional, modern, terpercaya), menjadi sangat mendesak.

Makna profesional secara umum dapat dijabarkan dalam indikator-indikator sebagai berikut:

1. Para pekerja/ petugasnya memiliki keahlian/ setidaknya memiliki kompetensi

2. Pekerjaan yang dilakukan jelas dan terukur berdasar pada standardisasi input, proses maupun outputnya

3. Produk-produk kinerjanya secara signifikan dapat dirasakan hasilnya oleh masyarakat dalam pelayanan publik yang memenuhi standar kecepatan, ketepatan, keakurasian, transparansi, akuntabilitas, informasi maupun kemudahan mengakses

4. Etika kerja yang berbasis pada SOP yang berisi job description, job analysis, standardisasi keberhasilan tugas, sistem penilaian kinerja, sistem reward and punishment.

Dalam rangka mengembangkan sistem yang modern Polri terus melakukan upaya pembaharuan di segala sektor, makna modern yang dimaksud tentu dilihat dari sistem-sistem yang dibangun mengikuti era digital, ada back office, aplikasi, dan network sehingga dapat memberikan pelayanan 24 jam sehari dan 7 hari seminggu secara proaktif dan problem solving, yang didukung dengan sistem-sistem komunikasi, koordinasi, komando pengendalian dan informasi yang berbasis pada implementasi teknologi dan informasi. Makna terpercaya adalah dapat diunggulkan dan kinerjanya dirasakan membawa manfaat bagi masyarakat dengan adanya keamanan dan rasa aman.

Dalam merespon perubahan dan tantangan reformasi menuju Polri yang promoter membutuhkan upaya reengginering ${ }^{3}$ dari semua proses, mulai dari proses seleksi hingga implementasi seluruh kinerja Polri. Proses pelaksanaan rekrutmen anggota polri baik itu Tantama, Bintara, SIPSS dan Taruna Akpol harus dilakukan secara objektif dan jujur, salah satu kebijakan yang telah ditetapkan adalah rekrutmen dengan menerapkan prinsip BETAH (bersih, transparan, akuntabel dan humanis). Rekrutmen yang bersih merupakan perintah Kapolri dan juga arahan Presiden Jokowi saat melantik Kapolri.

\footnotetext{
${ }^{1}$ Barda Nawawi, Bunga Rampai Kebijakan Hukum Pidana, PT. Citra Aditya Bakti, Bandung, 2005, hlm., 5 .

${ }^{2}$ Undang-undang No.2 Tahun 2002 tentang Kepolisian Negara Republik Indonesia.

3 Reengineering adalah pemikiran kembali secara fundamental dan perancangan kembali proses bisnis secara radikal, dihasilkan dari sumber daya organisasi yang tersedia
} 
Guna mengurangi dan menghindari kecurangan dan adanya oknum yang memanfaatkan pelksanaan rekrutmen tersebut, Polri menerapkan prinsip BETAH. Proses rekrutmen POLRI telah dilakukan dengan proses one day service (nilai hasil ujian harus dimunculkan hari itu juga) baik secara langsung ataupun melalui Aplikasi. Selain itu juga Polri telah membentuk tim pengawas baik pengawas internal dan eksternal yang independent dan professional.

Implementasi prinsip BETAH (bersih, transparan, akuntabel dan humanis) telah dilakukan oleh Polri telah dilaksanakan sejak tahapan selakesi mulai dari pendaftaran, verifikasi berkas, pemeriksaan administrasi, tes kesehatan tahap 1, tes psikologi tahap 1, uji kesamaptaan, tes akademik, pemeriksaan kesehatan tahap 2, pendalaman PMK, tes psikologi tahap 2, hingga pemeriksaan administrasi akhir.

Melalui penelitian dan survey ini, SDM Polri bersama dengan Lembaga Kajian Strategis Kepolisian Indonesia (LEMKAPI) telah melakukan diskusi dan kajian yang mendalam untuk menentukan indicator-indikator dari variable-variabel BETAH. Variabel bersih dapat diartikan bahwa tidak ada celah sama sekali bagi panitia, pejabat, calon dan keluarga peserta seleksi untuk melakukan tindak KKN. Adanya implementasi variable bersih juga telah ditunjukan dengan adanya peandatangan pakta integritas oleh peserta, panitia, orang tua dan juga pengawas baik internal maupun eksternal.

Berdasarkan latar belakang di atas, Polri sebagai instansi yang selalu menjadi sorotan masyarakat harus bisa menampilkan kinerja yang baik dan maksimal dalam melaksanakan peran dan fungsinya, khususnya dalam hal rekrutmen. Sehingga dapat diterima serta menimbulkan persepsi yang baik di tengah masyarakat.

1. Bagaimana realisasi prinsip BETAH (bersih, transparan, akuntabel, dan humanis) dalam proses penyelenggaraan rektrutmen anggota Polri ?

2. Bagaimana persepsi dan tanggapan masyarakat terhadap proses rekrutmen Polri?

\section{METODE PENELITIAN}

\section{Jenis dan sumber data}

Jenis data yang digunakan adalah berupa cross-sectional data, karena tim riset LEMKAPI mengumpulkan data hanya saat riset lapangan, yaitu mulai tanggal 26 Agustus 2020 sampai dengan 25 November 2020. Sedangkan berdasarkan sumbernya, data yang digunakan dalam penelitian ini bersifat primer dan sekunder, dengan rincian sebagai berikut.

\subsection{Data Primer (primary data)}

Lemkapi memperoleh data primer melalui penyebaran kuisioner (daftar pertanyaan) untuk diisi oleh peserta seleksi, panitia seleksi, pengawas internal dan eksternal, orang tua peserta seleksi dan tokoh masyarakat yang telah ditetapkan sebagai responden representative untuk menilai implementasi prinsip BETAH yang ditentukan dengan beberapa variable dan indicator penialaian kinerja. Kuesioner tersebut disusun berdasarkan variabel-variabel dalam penelitian, dengan menyediakan berbagai alternatif jawaban.

Kuisioner disajikan dalam bentuk pertanyaan tertutup dan pertanyaan terbuka. Pertanyaan tertutup disusun dengan menggunakan skala interval untuk memperoleh 
data yang jika diolah dapat membuktikan penilaian variabel dalam penilaian peserta seleksi, panitia seleksi, pengawas internal dan eksternal, orang tua peserta seleksi dan tokoh masyarakat untuk menilai implemetasi prinsip BETAH.

Sementara itu, pertanyaan terbuka digunakan untuk mendukung argumentasi kualitatif dari data kuantitatif yang diperoleh, serta sebagai dasar rekomendasi dalam setiap kebijakan, program, layanan SDM Polri dalam melaksanakan rekrutmen Polri baik itu ditujukan kepada peserta seleksi, panitia seleksi, pengawas internal dan eksternal, orang tua peserta seleksi dan tokoh masyarakat.

Selain dengan menggunakan kuesioner, riset yang LEMKAPI lakukan juga menggunakan teknik wawancara sebagai pendahuluan untuk mendukung akurasi jawaban yang terformulasi dalam kuesioner tersebut.

Teknik wawancara ini berguna untuk memperluas pandangan LEMKAPI tentang datadata kualitatif dari responden (masyarakat), dan nantinya akan berguna dalam penentuan implikasi strategis bagi kinerja SDM Polri dalam melaksanakan rekrutmen Polri baik itu ditujukan kepada peserta seleksi, panitia seleksi, pengawas internal dan eksternal, orang tua peserta seleksi dan tokoh masyarakat.

\subsection{Data sekunder (secondary data)}

Data sekunder dalam penelitian ini diperoleh dengan mengadakan kajian pustaka dari sumber-sumber penelitian terdahulu, serta referensi-referensi yang berkaitan dengan penilaian peserta seleksi, panitia seleksi, pengawas internal dan eksternal, orang tua peserta seleksi dan tokoh masyarakat terhadap proses rekrutmen Polri terutama sejauh mana implemetasi prinsip BETAH dalam seluruh tahapan seleksi anggota Polri.

Selain itu juga, kami juga mengumpulkan beberapa referensi penelitian terdahulu terkait survey dan catatan-catatan tentang penilaian serta survey yang berkaitan dengan Polri, dan artikel yang membahas tentang POLRI pada umumnya. Data sekunder tersebut bermanfaat sebagai dokumentasi untuk mengingat data lama, memprediksi kenyataan di lapangan, serta sebagai pembanding yang relevan.

\section{Populasi dan sampel}

Dalam penelitian ini, populasi yang digunakan mencakup peserta seleksi calon anggota Polri baik taruna Akpol, peserta seleksi calon anggota Polri dari Bintara Polri dan peserta seleksi calon anggota Polri dari Tamtama tahun penerimaan 2020. Populasi tersebut merupakan keseluruhan data peserta seleksi penerimaan anggota Polri yang terdaftar dan juga mereka yang telah menandatangani pakta integritas sebelum mengikuti proses seleksi. Hal ini merupakan wujud komitment anggota polri agar memiliki integritas. Berikut ini merupakan Tabel yang kami dapatkan dari SDM Mabes Polri untuk tahun penerimaan anggota Polri Tahun 2020 sebagai berikut: 
Tabel 2.2.1 Populasi peserta seleksi calon anggota taruna Akpol, Bintara dan Tamtama tahun penerimaan 2020.

\begin{tabular}{|l|l|l|l|l|}
\hline No & \multicolumn{1}{|c|}{ Populasi } & \multicolumn{2}{c|}{ Jenis Kelamin } & \multicolumn{1}{|c|}{ Total Populasi } \\
\hline & & Pria & Wanita & \\
\hline 1 & Akpol & 6.917 & 793 & 7.710 \\
\hline 2 & Bintara & 80.592 & 16.560 & 97.152 \\
\hline 3 & Tamtama & 6.266 & & 6.266 \\
\hline \multicolumn{2}{|l|}{ Total } & $\mathbf{9 3 . 7 7 5}$ & $\mathbf{1 7 . 3 5 3}$ & $\mathbf{1 1 1 . 1 2 8}$ \\
\hline
\end{tabular}

Sumber: SDM Mabes Polri tahun 2020

Guna menghindari bias gender dalam penelitian ini, masing-masing sampel dari para peserta seleksi peerimaan anggota Polri tahun 2020 dari tabel di atas untuk selanjutnya dilakukan penentuan sampel berdasarkan jenis kelamin, yang ditunjukan dalam tabel berikut:

Tabel 2.2.2 Sampel berdasarkan jenis kelamin

\begin{tabular}{|c|c|c|c|c|}
\hline \multirow[t]{2}{*}{ No } & \multirow[t]{2}{*}{ Peserta Seleksi } & \multicolumn{3}{|c|}{ Sample } \\
\hline & & Pria & Wanita & Total \\
\hline 1 & Akpol & 25 & 3 & 28 \\
\hline 2 & Bintara & 289 & 59 & 349 \\
\hline 3 & Tamtama & 22 & - & 22 \\
\hline \multicolumn{2}{|c|}{ Total } & 337 & 62 & 399 \\
\hline
\end{tabular}

Sumber: SDM Mabes Polri 2020

\section{PEMBAHASAN}

\section{Prinsip BETAH (Bersih, transparan, akuntabel, humanis)}

Survei yang dilakukan pada dasarnya untuk mengukur sejauh mana implementasi prinsip BETAH pada saat tahapan seleksi penerimaan anggota Polri dari Tingkat Tamtama sampai dengan calon Taruna Akpol. Polri

Hasil survei media yang efektif dalam menyampaikan informasi rekrutmen 
Dari mana anda mengetahui informasi rekrutmen angota POLRI?

399 responses
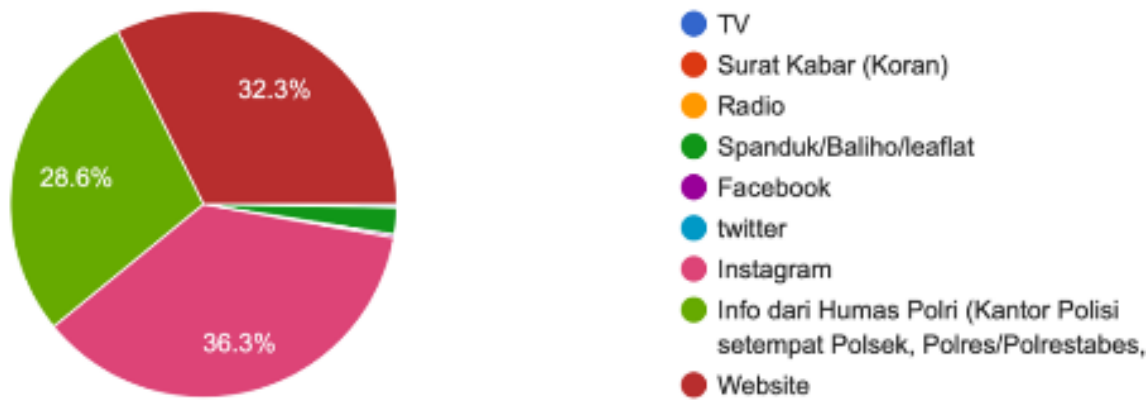

Dari hasil survei yang dilakukan tanggal 26 Agustus 2020 sampai dengan 25 November 2020 sebanyak 399 reponden mengetahui informasi tentang pendaftaran anggota Polri tahun 2020 melalui Instagram yaitu sebesar 36,3 persen. Sedangkan 32,3 persen responden melalui website dan 28,6 persen melalui humas polri kemudian sisanya sebesar 2,8 persen mendapatkan informasi dari spanduk/baliho/leaflat. Dari data tersebut menunjukan bahwa media sosial seperti FaceBook, twitter kurang mendapat perhatian dari para pendaftar anggota Polri. Selain itu karena sebagian besar reponden adalah kalangan milenial, maka media elektronik seperti TV dan radio kurang menjadi perhatian mereka, hal tersebut juga berlaku untuk media cetak seperti surat kabar, yang juga tidak mendapat perhatian dari para pendaftar.

Hasil survei dalam seleksi penerimaan anggota Polri yang dilaksanakan dengan bersih, jujur, bebas KKN dan tanpa adanya kecurangan

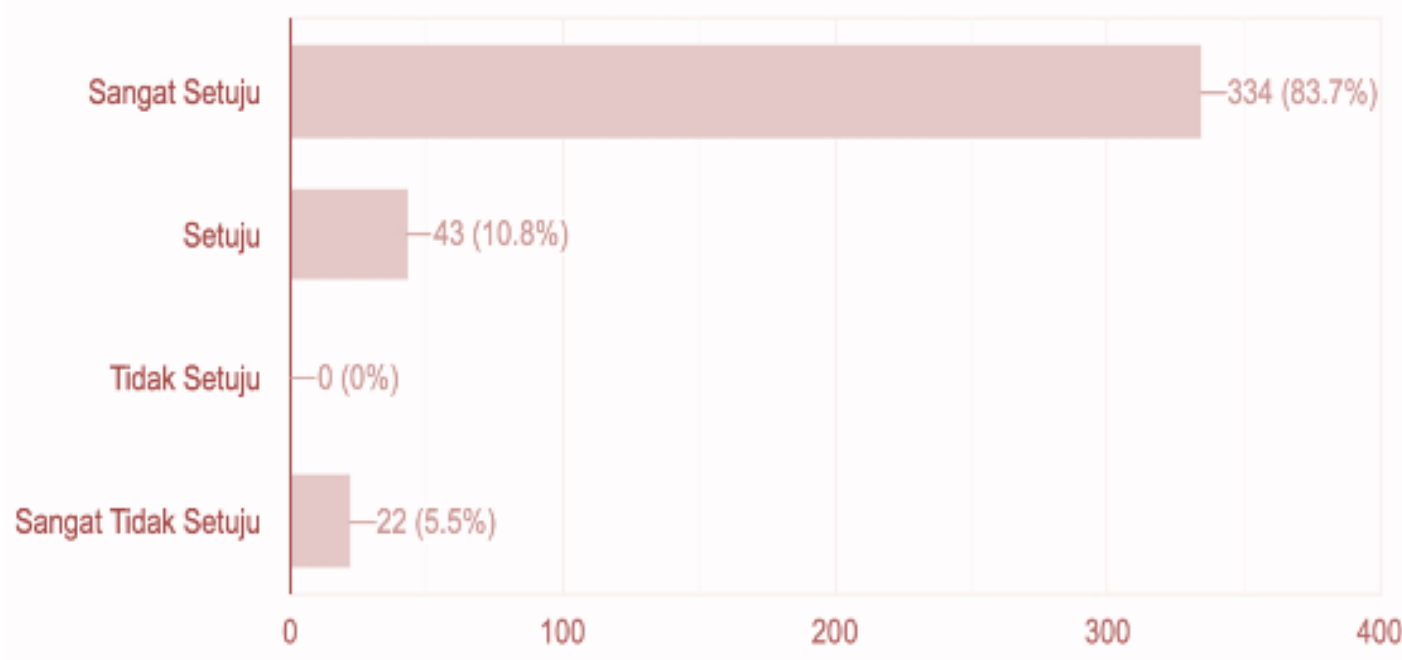

Hasil survei dilakukan tanggal 26 Agustus 2020 sampai dengan 25 November 2020. Dari total 399 reponden, sebesar 83,7 persen (334 responden) mengatakan "sangat setuju" bahwa penerimaan anggota Polri tahun 2020 telah dilaksanakan dengan bersih, jujur, bebas KKN dan tanpa adanya kecurangan dan 10,8 persen (43 responden) mengatakan "setuju" bahwa penerimaan anggota Polri tahun 2020 telah dilaksanakan dengan bersih, jujur, bebas KKN dan tanpa adanya kecurangan.

Tetapi disatu sisi dari hasil survei tersebut ada 22 responden atau sebesar 5,5 persen mengatakan "sangat tidak setuju". Meskipun hanya 5,5 persen akan namun temuan dari survei tersebut dapat menjadi bahan evaluasi bagi SDM Polri dan seluruh panitia baik di tingkat daerah maupun pusat. Bahwa masih ada stigma pada sebagian 
kecil peserta seleksi bahwa penerimaan anggota Polri tahun 2020 masih belum bersih, belum jujur, masih terdapat praktik KKN serta masih terdapat kecurangan.

Tidak terdapat oknum yang menjanjikan kelulusan dengan imbalan uang

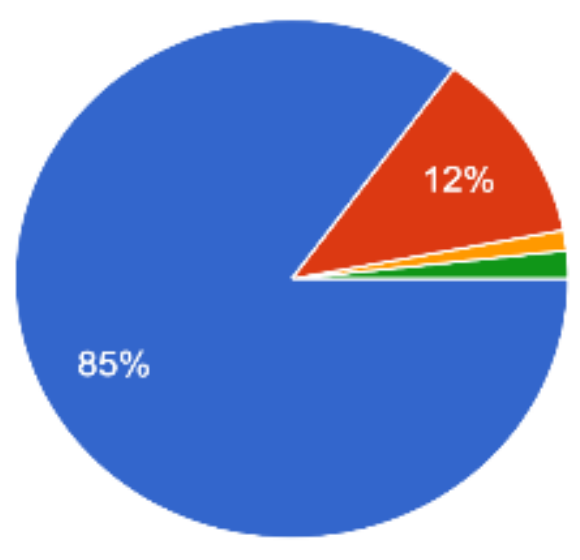

\author{
Sangat Setuju \\ Setuju \\ Tidak Setuju \\ Sangat Tidak Setuju
}

Hasil survei dilakukan tanggal 26 Agustus 2020 sampai dengan 25 November 2020. Dari total 399 reponden, sebesar 85 persen reponden mengatakan "sangat setuju" bahwa tidak terdapat Oknum yang menjanjikan kelulusan dengan imbalan uang, 12 persen mengatakan "setuju" bahwa tidak terdapat Oknum yang menjanjikan kelulusan dengan imbalan uang. Hanya sebesar 2 persen mengatakan "tidak setuju" dan 3 persen mengatakan "sangat tidak setuju", menunjukan kemungkinan bahwa masih terdapat Oknum yang menjanjikan kelulusan dengan imbalan uang.

Seluruh tahapan seleksi sudah dilaksanakan secara terbuka dan transparan
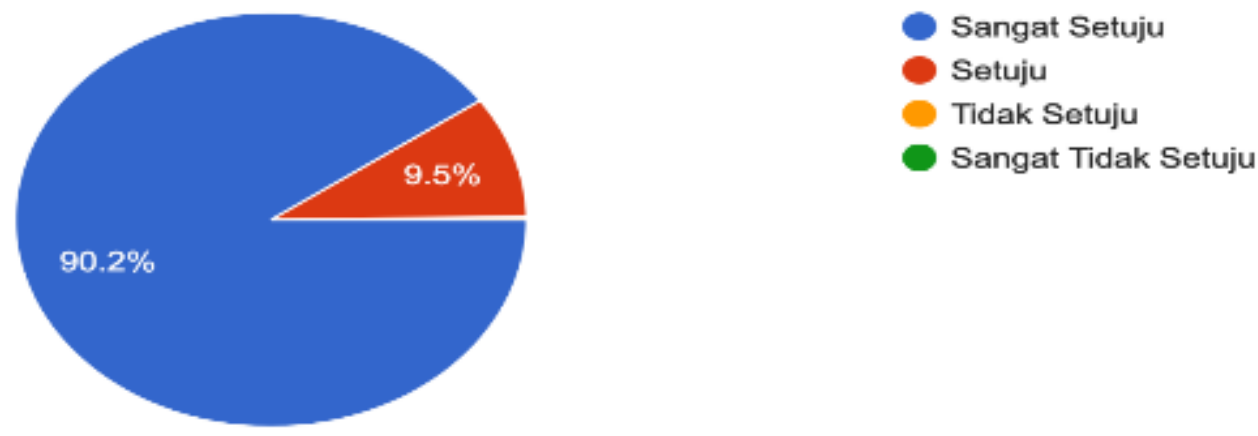

Hasil survei yang kami lakukan tanggal 26 Agustus 2020 sampai dengan 25 November 2020 sebanyak 399 reponden menunjukan bahwa sebesar 90,2 persen responden berpendapat bahwa "sangat setuju" seluruh tahapan seleksi sudah dilaksanakan secara terbuka dan transparan dan 9,5 persen responden mengatakan "setuju" bahwa seluruh tahapan seleksi sudah dilaksanakan secara terbuka dan transparan. Artinya bahwa tingkat kepercayaan responden terhadap tahapan seleksi terlah dilaksanakan terbuka dan transparan sangat tinggi.

Sudah dilakukan pengawasan dalam seluruh tahapan seleksi penerimaan anggota POLRI baik itu dari pengawas internal maupun eksternal 


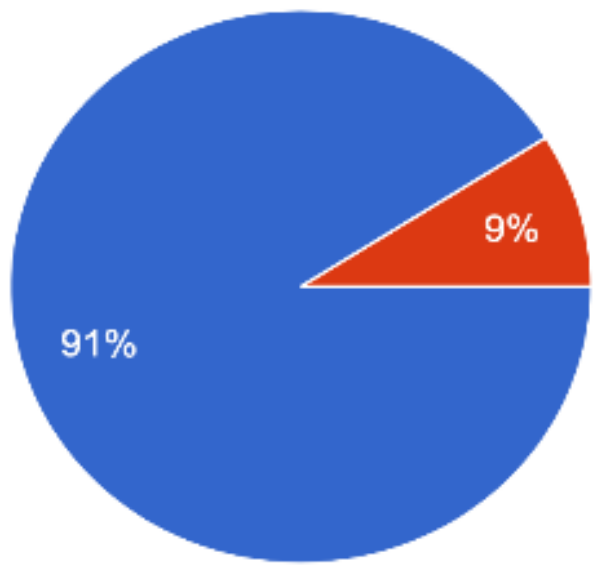

\author{
Sangat Setuju \\ Setuju \\ Tidak Setuju \\ Sangat Tidak Setuju
}

Hasil survei yang kami lakukan tanggal 26 Agustus 2020 sampai dengan 25 November 2020 sebanyak 399 reponden menunjukan bahwa sebesar 91 persen responden berpendapat bahwa "sangat setuju" sudah dilakukan pengawasan dalam seluruh tahapan seleksi penerimaan anggota POLRI baik itu dari pengawas internal maupun eksternal dan ada 9 persen responden mengatakan "setuju" bahwa sudah dilakukan pengawasan dalam seluruh tahapan seleksi penerimaan anggota POLRI baik itu dari pengawas internal maupun eksternal.

Tidak terdapat manipulasi atapun kecurangan dalam seluruh tahapan seleksi penerimaan anggota Polri

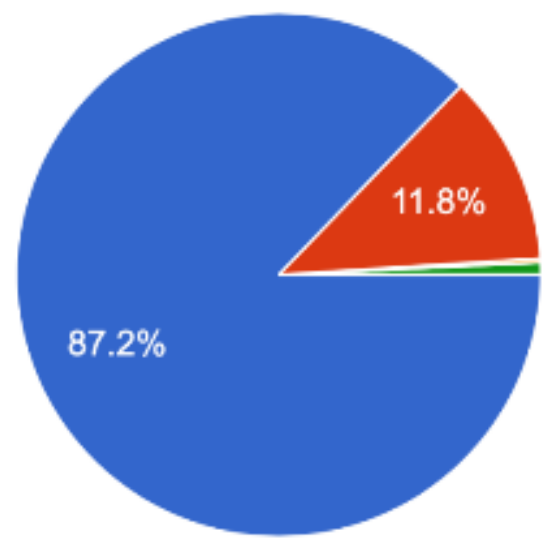

\author{
Sangat setuju \\ Setuju \\ Tidak Setuju \\ Sangat Tidak Setuju
}

Dari hasil survei tersebut menunjukan bahwa 87,2 persen responden mengatakan "sangat setuju" bahwa tidak terdapat manupulasi atau kecurangan dalam seluruh tahapan seleksi penerimaan anggota Polri, 11,8 persen mengatakan "setuju" bahwa tidak terdapat manupulasi atau kecurangan dalam seluruh tahapan seleksi penerimaan anggota Polri. Sedangkan hanya 1 persen yang mengatakan bahwa masih terdapat manupulasi atau kecurangan dalam seluruh tahapan seleksi penerimaan anggota Polri. 
Adanya keterbukaan informasi skor dan penilaian hasil seleksi secara transparan

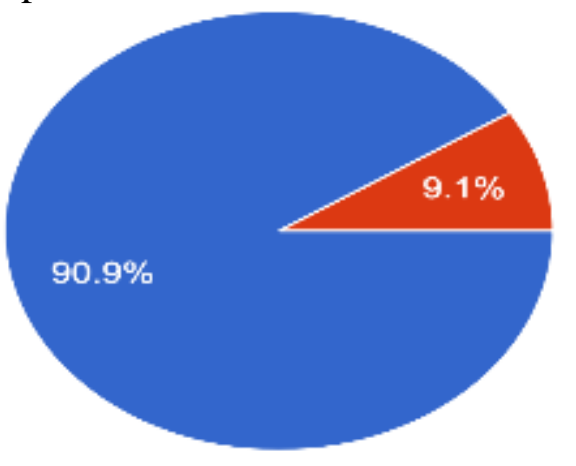

\author{
Sangat Setuju \\ Setuju \\ Tidak Setuju \\ Sangat Tidak Setuju
}

Hasil survei di atas menunjukan bahwa 90,9 persen responden mengatakan "sangat setuju" bahwa terdapat keterbukaan informasi skor dan penilaian seleksi secara transparan. Selanjutnya terdapat 9,1 persen responden mengatakan "setuju" bahwa terdapat keterbukaan informasi skor dan penilaian dan juga seleksisudah dilakukan secara transparan.

Panitia memegang dan mematuhi aturan dan kode etik selama tahapan seleksi

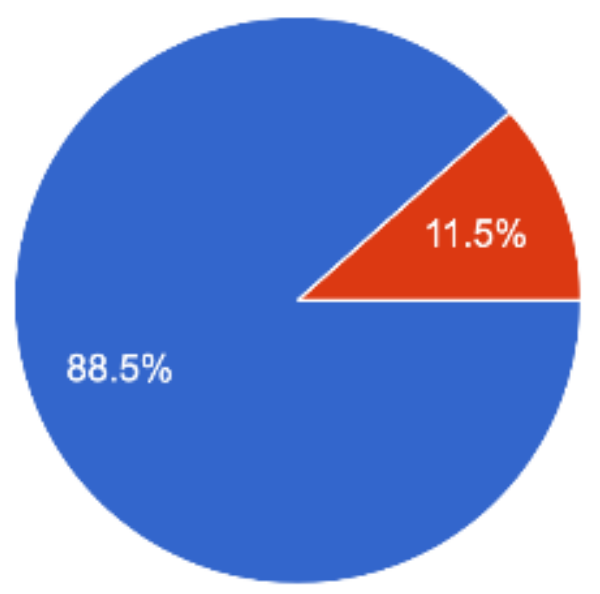

\author{
Sangat setuju \\ Setuju \\ Tidak setuju \\ Sangat tidak setuju
}

Hasil survei menunjukan bahwa 88,5 persen responden mengatakan "sangat setuju" bahwa panitia memegang dan mematuhi aturan dan kode etik selama tahapan seleksi. Terdapat 11,5 persen responden mengatakan "setuju" bahwa panitia memegang dan mematuhi aturan dan kode etik selama tahapan seleksi. Artinya bahwa tingkat kepercayaan responden terhadap panitia telah memegang dan mematuhi kode etik selama tahapan seleksi. 
Panitia dalam melakukan tugas dan fungsinya sudah bekerja secara sistematis

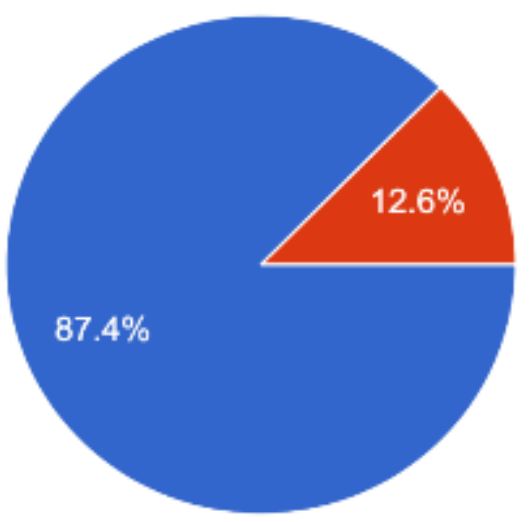

\author{
Sangat Setuju \\ Setuju \\ Tidak Setuju \\ Sangat Tidak Setuju
}

Hasil survei menunjukan bahwa 87,4 persen responden mengatakan "sangat setuju" bahwa panitia dalam melakukan tugas dan fungsinya sudah bekerja secara sistematis, sebesar 12,6 persen mengatakan "setuju" bahwa panitia dalam melakukan tugas dan fungsinya sudah bekerja secara sistematis.

Panitia sudah sangat independen dan tidak dapat dintervesnsi atau dipengaruhi oleh pihak lain

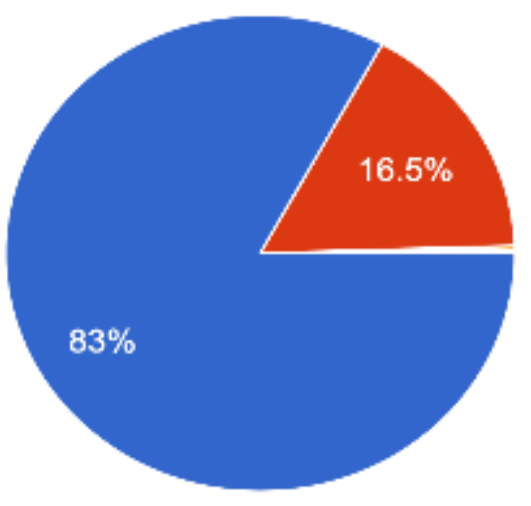

Sangat independen

Independen

Tidak independen

Sangat tidak independen

Hasil survei menunjukan bahwa 83 persen responden mengatakan "sangat setuju" bahwa panitia sudah sangat independen dan tidak dapat dintervesnsi atau dipengaruhi oleh pihak lain. Ada 16,5 persen responden mengatakan "setuju" bahwa panitia sudah sangat independen dan tidak dapat dintervesnsi atau dipengaruhi oleh pihak lain dan hanya 0,5 persen responden mengatakan panitia tidak independen dan dapat dintervesnsi atau dapat dipengaruhi oleh pihak lain.

Proses dan hasil seleksi Polri dapat dipertanggung jawabkan kepada publik.
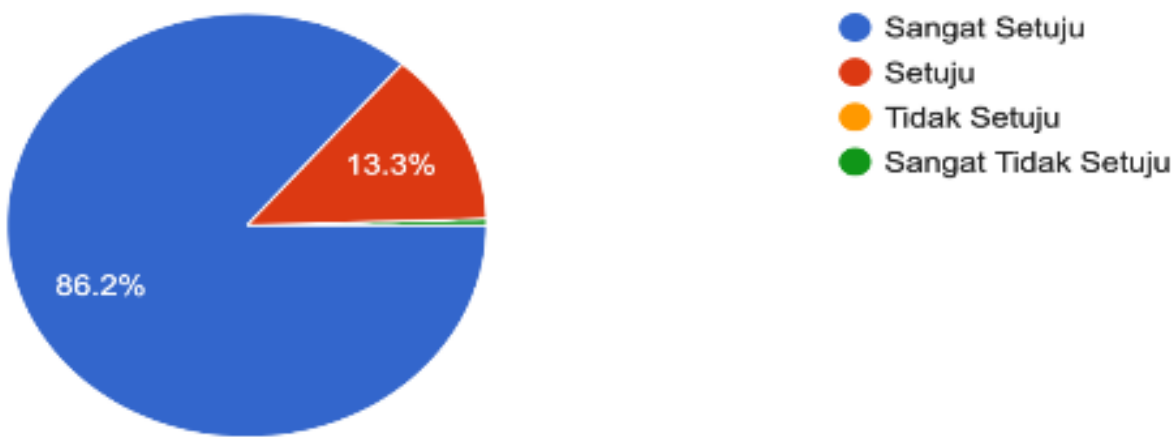
Hasil survei menunjukan bahwa 86,2 persen responden mengatakan "sangat setuju" bahwa proses dan hasil seleksi penerimaan anggota Polri dapat dipertanggung jawabkan kepada publik. Terdapat 13,3 persen mengatakan "setuju" bahwa proses dan hasil seleksi penerimaan anggota Polri dapat dipertanggung jawabkan kepada public. Sedangkan hanya 0,5 persen mengatakan "sangat tidak setuju" bahwa proses dan hasil seleksi penerimaan anggota Polri dapat dipertanggung jawabkan kepada publik.

Bagaimana Penerapan protokol pencegahan COVID 19 oleh Panitia

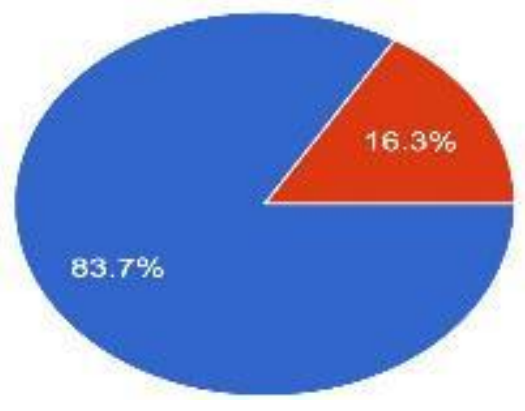

Sangat baik dan profesional

Baik dan profesional

Tidak baik

Sangat tidak baik

Terkait dengan penerapan protocol kesehatan dalam upaya pencegahan penyebarluasan Covid 19, seluruh panitia baik itu dari panitia pusat hingga daerah sudah mematuhi protocol yang berlaku. Bahkan setiap tahapan seleksi panitia sudah memiliki SOP khusus dalam rangka upaya pencegahan penyebarluasan Covid 19.

Hasil survei yang telah dilakukan menunjukan bahwa 83,7 persen responden mengatakan bahwa penerapan protocol kesehatan dalam rangka pencegahan penyebarluasan Covid 19 telah dilakukan dengan sangat baik dan sangat professional. 16,3 persen responden juga mengatakan bahwa penerapan protocol kesehatan dalam rangka pencegahan penyebarluasan Covid 19 telah dilakukan dengan baik dan professional.

Riset dan survei yang kami lakukan terkait dengan implementasi prinsip BETAH (bersih, transparan, akuntabel dan humanis) tidak hanya melibatkan peserta seleksi saja sebagai responden. Namun melibatkan Masyarakat, Panitia, Pengawas baik itu internal dan eksternal serta orang tua peserta seleksi.

\subsection{Point-Point Krusial Kepuasan Terhadap Rekrutmen POLRI oleh Masyarakat, Panitia, Pengawas dan Orang Tua Peserta Seleksi}

Mengingat pihak-pihak ekternal terutama masyarakat umum masih memiliki stigma negatif bahwa reformasi Polri yang dimulai dari seleksi penerimaan anggota dengan menggunakan prinsip-prinsip BETAH masih belum banyak diketahui oleh public. Untuk itu kami berharap agar hasil temuan dan rekomendasi dari penelitian ini dapat dipublikasikan secara massif kepada masyarakat luas agar isu-isu minor tentak praktek KKN, transaksi dan isu tentang penembak berkuda dapat diminimalisir melalui strategi kehumasan yang tepat.

Untuk itu berikutnya akan dibahas tentang Point-Point Krusial Kepuasan Terhadap Rekrutmen POLRI oleh Masyarakat, Panitia, Pengawas dan Orang Tua Peserta Seleksi berikut ini. 
Dari mana anda mengetahui informasi rekrutmen angota POLRI?
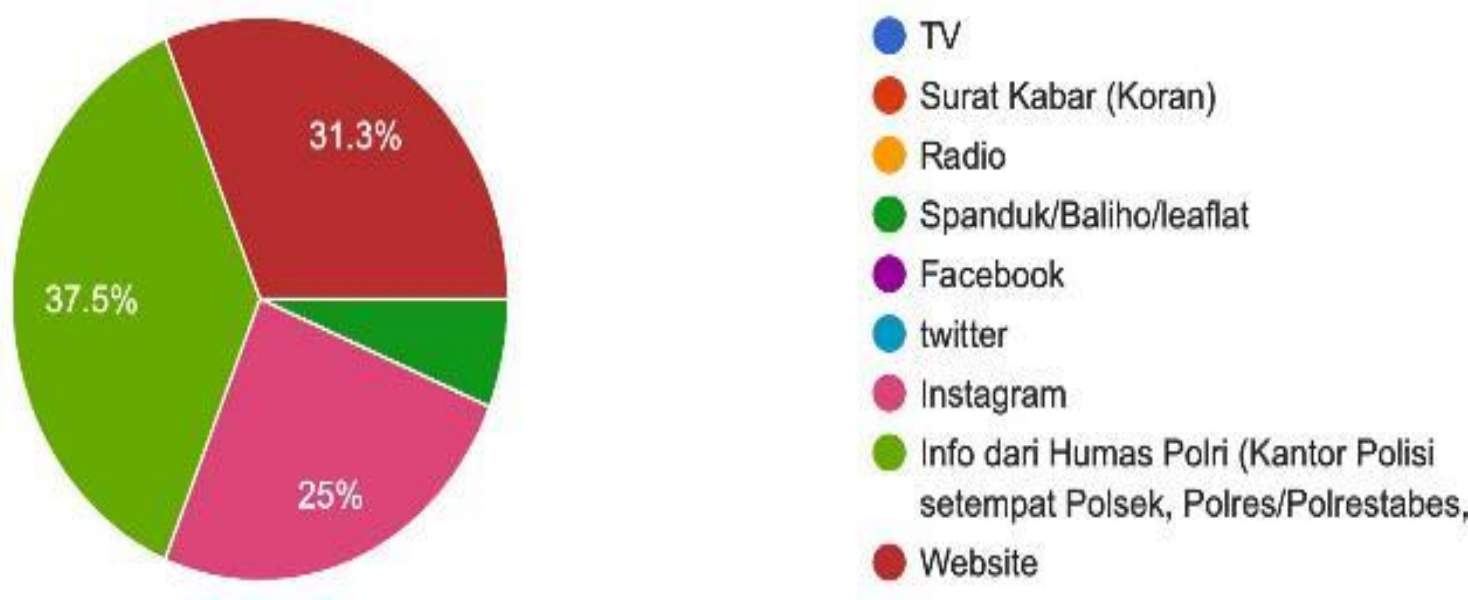

Dari hasil survei yang kami lakukan tanggal 26 Agustus 2020 sampai dengan 25 November 2020 sebanyak 50 responden dari Masyarakat, Panitia, Pengawas baik itu internal dan eksternal serta orang tua peserta seleksi, hasil survei menunjukan bahwa responden mengetahui informasi tentang pendaftaran anggota Polri tahun 2020 melalui informasi dari humas polri (kantor polisi setempat dari polsek, polres dan polda) sebesar 37,5 persen.

Sedangkan informasi dari Instagram yaitu sebesar 25 persen. Dari website sebesar 31,3 persen responden dan sisanya sebesar 6,3 persen mendapatkan informasi dari spanduk/baliho/leaflat. Dari data tersebut menunjukan bahwa media sosial seperti FaceBook, twitter kurang mendapat perhatian dari para responden (masyarakat).

Tidak terdapat Oknum yang menjanjikan kelulusan dengan imbalan uang
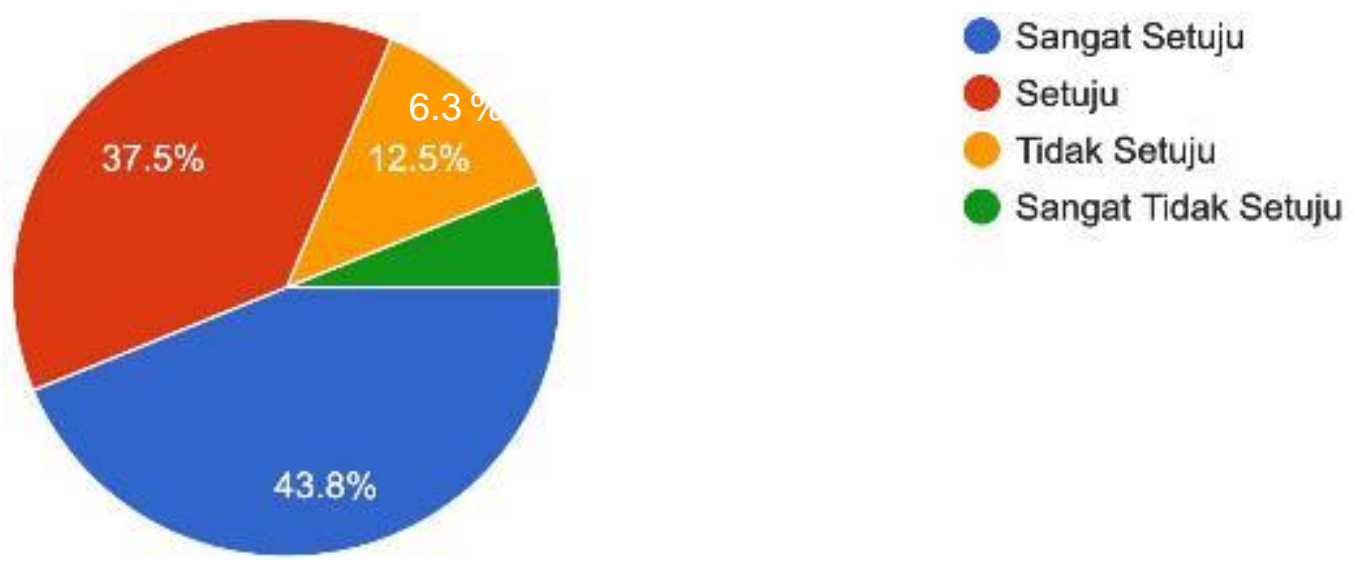

Hasil survei yang kami lakukan tanggal 26 Agustus 2020 sampai dengan 25 November 2020 sebanyak 50 responden dari Masyarakat, Panitia, Pengawas baik itu internal dan eksternal serta orang tua peserta seleksi, hasil survei menunjukan bahwa sebesar 43,8 persen reponden mengatakan "sangat setuju" bahwa tidak terdapat Oknum yang menjanjikan kelulusan dengan imbalan uang, 37,5 persen mengatakan "setuju" bahwa tidak terdapat Oknum yang menjanjikan kelulusan dengan imbalan uang. Sebesar 12,5 persen mengatakan "tidak setuju" dan 6,3 persen mengatakan 
"sangat tidak setuju" bahwa masih terdapat Oknum yang menjanjikan kelulusan dengan imbalan uang.

Sudah dilakukan pengawasan dalam seluruh tahapan seleksi

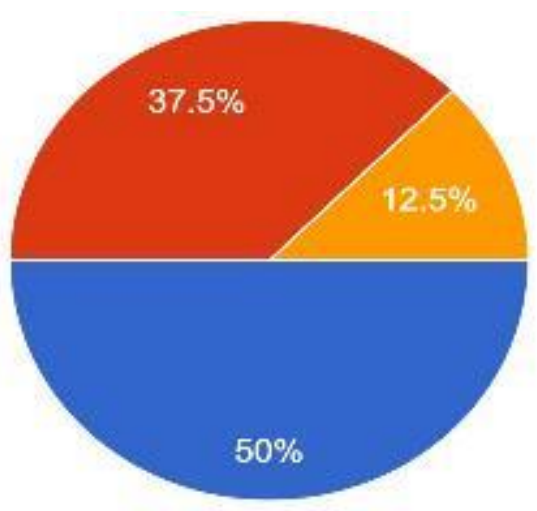

\author{
Sangat Setuju \\ Setuju \\ Tidak Setuju \\ Sangat Tidak Setuju
}

Hasil survei yang kami lakukan tanggal 26 Agustus 2020 sampai dengan 25 November 2020 sebanyak 50 responden dari Masyarakat, Panitia, Pengawas baik itu internal dan eksternal serta orang tua peserta seleksi, hasil survei menunjukan bahwa sebesar 50 persen responden berpendapat bahwa "sangat setuju" sudah dilakukan pengawasan dalam seluruh tahapan seleksi. Ada 37,5 persen responden mengatakan "setuju". Akan tetapi ada 12,5 persen responden mengatakan bahwa "tidak setuju" sudah dilakukan pengawasan dalam seluruh tahapan seleksi.

Tidak terdapat manipulasi atapun kecurangan dalam seluruh tahapan seleksi penerimaan anggota POLRI

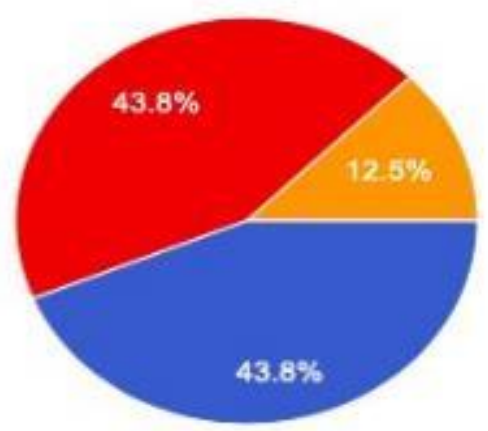

Sangat setuju

Setuju

Tidak Setuju

Sangat Tidak Setuju

Hasil survei menunjukan bahwa sebesar 43,8 persen responden berpendapat bahwa "sangat setuju" bahwa tidak terdapat manipulasi ataupun kecurangan dalam seluruh tahapan seleksi penerimaan anggota Polri. Ada 43,8 persen responden juga mengatakan "setuju" bahwa tidak terdapat manipulasi ataupun kecurangan dalam seluruh tahapan seleksi penerimaan anggota Polri. Akan tetapi ada 12,5 persen responden mengatakan bahwa "tidak setuju" atau masih berpandangan bahwa masih terdapat manipulasi ataupun kecurangan dalam seluruh tahapan seleksi penerimaan anggota Polri. 
Telah memberikan informasi keterbukaan skor dan penilaian hasil seleksi secara transparan

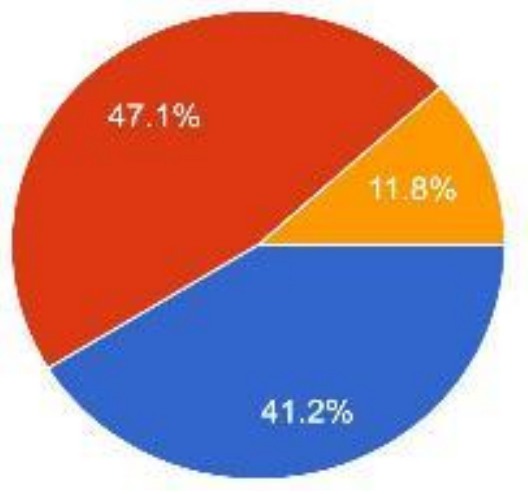

Sangat Setuju

Setuju

Tidak Setuju

Sangat Tidak Setuju

Hasil survei menunjukan bahwa sebesar 41,2 persen responden berpendapat bahwa "sangat setuju" bahwa panitia telah memberikan informasi keterbukaan skor dan penilaian hasil seleksi secara transparan. Ada 47,1 persen responden mengatakan "setuju" bahwa panitia telah memberikan informasi keterbukaan skor dan penilaian hasil seleksi secara transparan. Akan tetapi ada 11,8 persen responden mengatakan bahwa "tidak setuju" atau belum ada keterbukaan informasi keterbukaan skor dan penilaian hasil seleksi secara transparan.

Panitia memegang dan mematuhi aturan dan kode etik selama tahapan seleksi penerimaan anggota POLRI
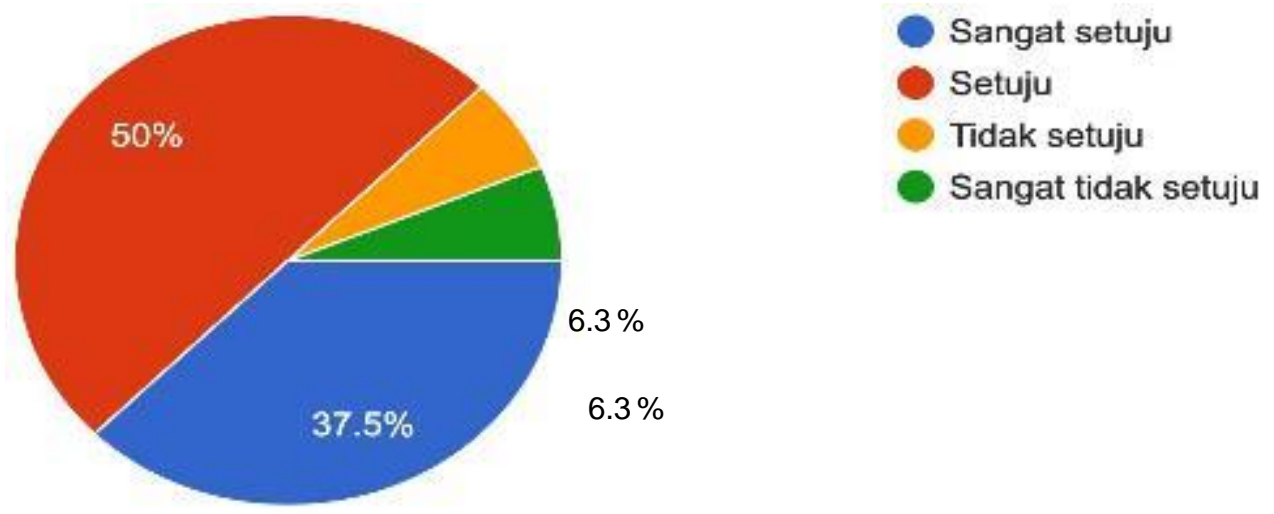

Hasil survei menunjukan bahwa sebesar 37,5 persen responden berpendapat bahwa "sangat setuju" bahwa panitia memegang dan mematuhi aturan dank ode etik selama tahapan seleksi. Ada 50 persen responden mengatakan "setuju" bahwa panitia panitia memegang dan mematuhi aturan dank ode etik selama tahapan seleksi. Akan tetapi ada 6,3 persen responden mengatakan bahwa "tidak setuju" dan ada 6,3 persen berpendapat "sangat tidak setuju". 
Panitia dalam melakukan tugas dan fungsinya sudah bekerja secara sistematis

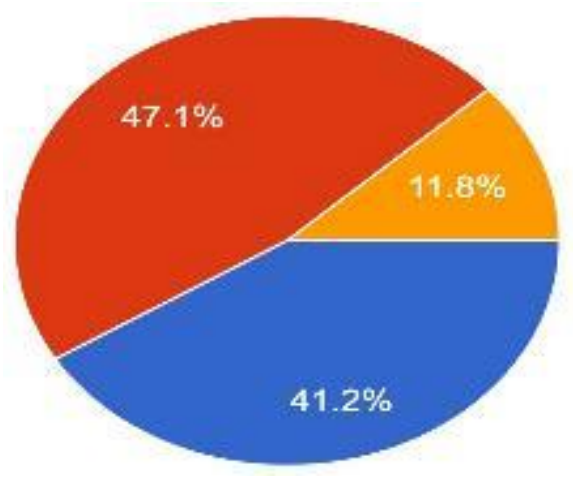

Sangat Setuju

Setuju

Tidak Setuju

Sangat Tidak Setuju

Hasil survei menunjukan bahwa sebesar 37,5 persen responden berpendapat bahwa "sangat setuju" bahwa panitia memegang dan mematuhi aturan dan kode etik selama tahapan seleksi. Ada 50 persen responden mengatakan "setuju" bahwa panitia panitia memegang dan mematuhi aturan dank ode etik selama tahapan seleksi. Akan tetapi ada 6,3 persen responden mengatakan bahwa "tidak setuju" dan ada 6,3 persen berpendapat "sangat tidak setuju".

Panitia sangat independen dan tidak dapat dintervesnsi atau dipengaruhi oleh pihak lain, baik pejabat Polri ataupun pihak eksternal lain

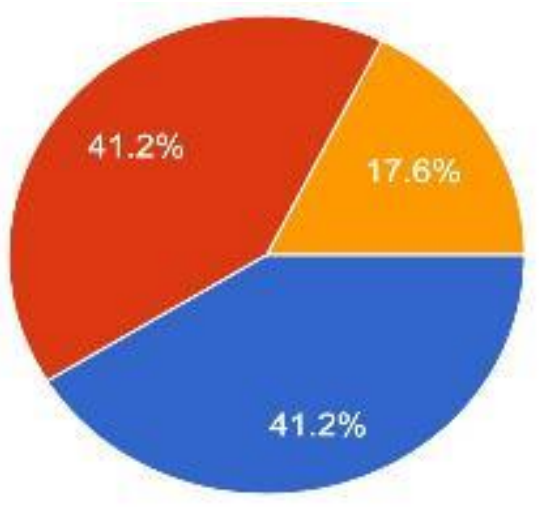

\section{Sangat independen \\ Independen \\ Tidak independen}

Sangat tidak independen

Hasil survei menunjukan bahwa sebesar 41,2 persen responden berpendapat bahwa "sangat setuju" bahwa Panitia sangat independen dan tidak dapat dintervesnsi atau dipengaruhi oleh pihak lain, baik pejabat Polri ataupun pihak eksternal lainya. Ada 41,2 persen responden mengatakan "setuju" bahwa Panitia sangat independen dan tidak dapat dintervesnsi atau dipengaruhi oleh pihak lain, baik pejabat Polri ataupun pihak eksternal lainya. Akan tetapi ada 17,6 persen responden mengatakan bahwa "tidak setuju". 
Proses dan hasil seleksi penerimaan anggota POLRI dapat dan telah disampaikan kepada publik

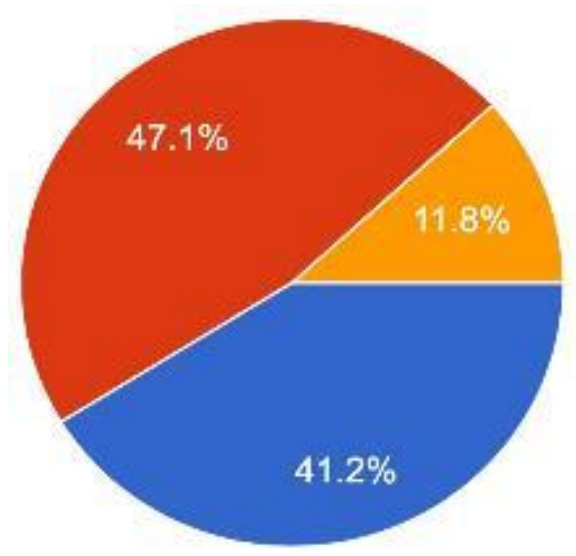

Sangat Setuju

Setuju

Tidak Setuju

Sangat Tidak Setuju

Hasil survei menunjukan bahwa sebesar 41,2 persen responden berpendapat bahwa "sangat setuju" bahwa proses dan hasil seleksi penerimaan anggota POLRI dapat dan telah disampaikan kepada publik. Ada 47,1 persen responden mengatakan "setuju" bahwa proses dan hasil seleksi penerimaan anggota POLRI dapat dan telah disampaikan kepada publik. Akan tetapi ada 11,8 persen responden mengatakan bahwa "tidak setuju".

Proses dan hasil seleksi penerimaan anggota POLRI dapat dipertanggung jawabkan kepada publik/masyarakat
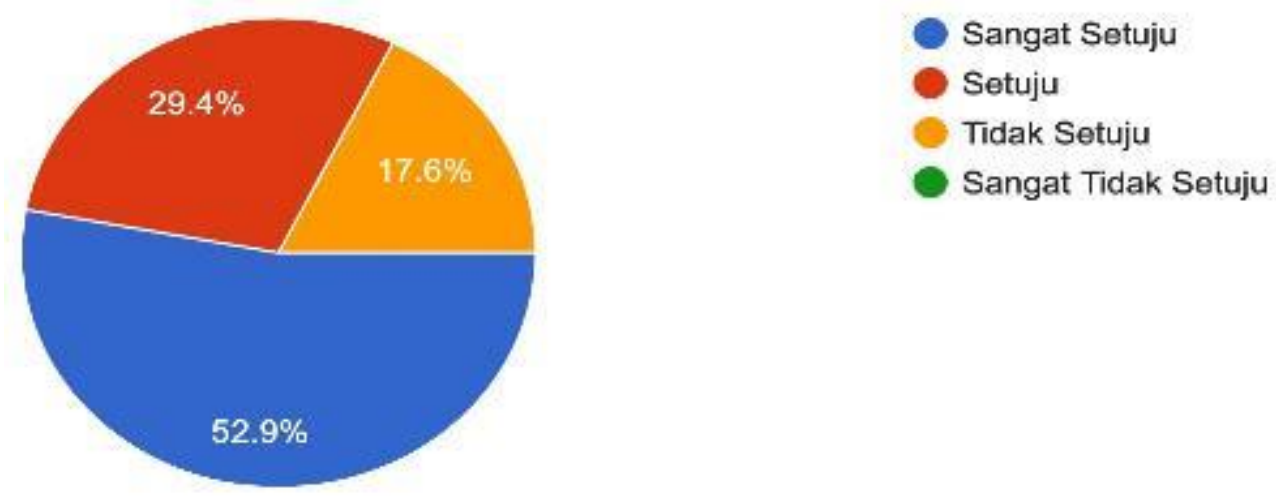

Hasil survei menunjukan bahwa sebesar 52,9 persen responden berpendapat bahwa "sangat setuju" bahwa proses dan hasil seleksi penerimaan anggota POLRI dapat dipertanggung jawabkan kepada publik/masyarakat. Ada 29,4 persen responden mengatakan "setuju" bahwa proses dan hasil seleksi penerimaan anggota POLRI dapat dipertanggung jawabkan kepada publik/masyarakat. Akan tetapi ada 17,6 persen responden mengatakan "tidak setuju". 

diskriminasi)

Panitia telah mengedepankan prinsip kemanusiaan dan keadilan (tanpa unsur

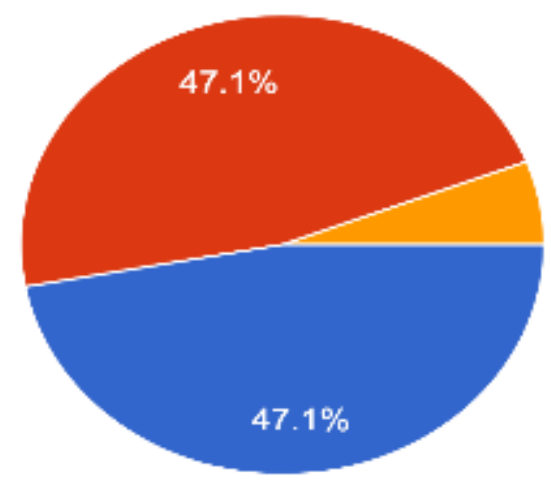

\author{
Sangat Setuju \\ Setuju \\ Tidak Setuju \\ Sangat Tidak Setuju
}

Hasil survei menunjukan bahwa sebesar 47,1 persen responden berpendapat bahwa "sangat setuju" bahwa panitia telah mengedepankan prinsip kemanusiaan dan keadilan (tanpa unsur diskriminasi). Ada 47,1 persen responden mengatakan "setuju" bahwa panitia telah mengedepankan prinsip kemanusiaan dan keadilan (tanpa unsur diskriminasi). Akan tetapi ada 5,9 persen responden mengatakan "tidak setuju".

Prinsip BETAH dan respon dari masyarakat apabila dilihat melalui hasil survey di atas maka dapat dikatakan telah memenuhi tingkat kepuasan yang baik, meskipun begitu respon dan persepsi negatif yang masih ada harus segera diperbaiki. Polri tentunya akan terus meningkatkan performa dan pelayanan karena tentunya sebagai penegak hukum dan pengayom, Polri selalu disorot dan dijadikan panutan bagi masyarakat.

\section{KESIMPULAN}

Dari riset yang telah dilakukan yang dilakukan pada tanggal 26 Agustus 2020 sampai dengan 25 November 2020 untuk mengukur sejauh mana implementasi prinsip BETAH pada saat tahapan seleksi penerimaan anggota Polri dari Tingkat Tamtama sampai dengan calon Taruna Akpol menyimpulkan hal-hal sebagai berikut :

1. Media informasi yang banyak diakses oleh peserta seleksi untuk mendapatkan informasi tentang pendaftaran Polri adalah Instagram sebesar 36,3\%, website $32,3 \%$ dan Humas Polri 28,6\%.

2. Dari survey tersebut menunjukan bahwa sebagian besar peserta seleksi berpendapat bahwa pada seluruh tahapan seleksi penerimaan anggota Polri telah mengimplementasikan prinsip-prinsip BETAH (Bersih, Transparan, Akuntabel dan Humanis).

3. Berdasarkan survey persepsi Masyarakat, sebagian besar layanan yang sering didapatkan selama setahun terakhir adalah Pembuatan dan perpanjangan SIM, Layanan SAMSAT dan pembuatan SKCK. Sebagian besar responden atau $50 \%$ responden mengatakan bahwa layanan yang mereka dapatkan sangat cepat, 43,8 \% mengatakan cepat dan 6,3\% mengatakan lambat.

4. Sedangkan persepsi masyarakat tentang implementasi prinsip-prinsip BETAH (Bersih, Transparan, Akuntabel dan Humanis) belum sepenuhnya di ketahui dan dipahami oleh masyarakat sebagai contohnya ada $18,8 \%$ responden 
beranggapan bahwa masih terdapat oknum yang menjanjikan kelulusan dengan imbalan uang; ada sebesar $12,5 \%$ responden mengatakan bahwa pengawasan dalam seluruh tahapan seleksi belum dilakukan; terdapat $12,5 \%$ responden masyarakat berpendapat bahwa masih terdapat manipulasi atapun kecurangan dalam seluruh tahapan seleksi.

\section{SARAN}

Dari riset yang telah dilakukan yang dilakukan pada tanggal 26 Agustus 2020 sampai dengan 25 November 2020 untuk mengukur sejauh mana implementasi prinsip BETAH pada saat tahapan seleksi penerimaan anggota Polri, berdasarkan temuan yang kami peroleh kami memberikan beberapa saran untuk perbaikan dan meningkatan profesionalisme serta kepercayaan public akan rekrutmen Polri. Dengan ini kami menyarankan hal-hal sebagai berikut :

1. Berdasarkan temuan di atas bahawa peserta seleksi lebih memiliki preverensi dengan media informasi dan sosial media seperti Instagram dan website untuk itu perlu adanya optimalisasi penggunaan media-media yang lain.

2. Sesuai dengan hasil survey yang menunjukan bahwa seluruh tahapan seleksi penerimaan anggota Polri telah mengimplementasikan prinsip-prinsip BETAH, untuk itu seluruh peserta harus menyampaikan kepada pihak-pihak eksternal atau masyarakat umum agar isu negatif (wacana minor) tentang seluruh tahapan seleksi anggota Polri tidak lagi ada di benak masyarakat.

3. Berdasarkan hasil survey dari responden masyarakat, masih terdapat masyarakat yang menganggap bahwa tahapan seleksi anggota Polri belum sepenuhnya bersih, transparan, akuntabel dan humanis. Untuk itu diperlukan strategi manajemen media dengan terus memproduksi wacana dan informasi tentang implementasi prinsip BETAH di tubuh Polri agar Polri menerapkan Profesionalisme, Modern dan Terpercaya. Stategi ini dapat dilakukan dengan merangkul stake holder eksternal seperti: Kalangan Pers, Akademisi, NGOs, Pegiat dan Pemerhati Kepolisian, Mahasiswa dan juga Tokoh Masyarakat.

\section{DAFTAR PUSTAKA}

\section{Buku}

H Siswanto S, 2012, Politik Hukum Dalam Undang-Undang Narkotika (UndangUndang Nomor 35 Tahun 2009), Cetakan Pertama, PT Rineka Cipta, Jakarta. Aruan Sakidjo dan Bambang Poernomo, 1990, Hukum Pidana: Dasar Aturan Umum Hukum Pidana Kodifikasi, Cetakan Pertama, Ghalia Indonesia, Jakarta.

Moeljatno, 2008, KUHP: Kitab Undang-Undang Hukum Pidana, Cetakan 27, PT Bumi Aksara, Jakarta.

\section{Website}

https://fh.umj.ac.id/eksekusi-pidana-mati-pasca-putusan-mahkamah-konstitusinomor-107puu-xiii2015/Dr. Chairul Huda, S.H, M.H. 